\title{
OPTIMIZATION OF NUTRITIONAL REQUIREMENTS FOR MYCELIAL GROWTH AND SPORULATION OF ENTOMOGENOUS FUNGUS ASCHERSONIA ALEYRODIS WEBBER
}

\author{
Yanping Zhu; Jieru Pan; Junzhi Qiu; Xiong Guan*
}

\begin{abstract}
Key Laboratory of Biopesticide and Chemical Biology, Ministry of Education, Fujian Agriculture and Forestry University, Fuzhou 350002, China
\end{abstract}

Submitted: September 14, 2007; Returned to authors for corrections: January 11, 2008; Approved: November 02, 2008.

\begin{abstract}
The objective of the present study was to investigate the optimal nutritional requirements for mycelial growth and sporulation of entomopathogenic fungus Aschersonia aleyrodis Webber by orthogonal layout methods. Herein the order of effects of nutrient components on mycelial growth was tryptone $>\mathrm{Ca}^{2+}>$ soluble starch $>$ folacin, corresponding to the following optimal concentrations: $1.58 \%$ Soluble Starch, $3.16 \%$ Tryptone, 0.2 mmol $1^{-1} \mathrm{Ca}^{2+}$ and $0.005 \%$ Folacin. The optimal concentration of each factors for sporulation was $1.16 \%$ lactose, $0.394 \%$ tryptone, $0.4 \mathrm{mmol} \mathrm{l}^{-1} \mathrm{Fe}^{2+}$ and $0.00125 \% \mathrm{~V}_{\mathrm{B} 1}$, and the effects of medium components on sporulation were found to be in the order lactose $>\mathrm{V}_{\mathrm{B} 1}>\mathrm{Fe}^{2+}>$ tryptone. Under the optimal culture conditions, the maximum production of mycelial growth achieved $20.05 \mathrm{~g} \mathrm{l}^{-1}$ after 7 days of fermentation, while the maximum spore yield reached $5.23 \times 10^{10}$ spores $1^{-1}$ after 22 days of cultivation. This is the first report on optimization of nutritional requirements and design of simplified semi-synthetic media for mycelial growth and sporulation of A. aleyrodis.
\end{abstract}

Key words: Entomogenous fungus, Aschersonia aleyrodis, Orthogonal matrix method, Mycelial Growth, Sporulation

\section{INTRODUCTION}

Aschersonia aleyrodis Webber belongs to Ascomycota; Pezizomycotina; Sordariomycetes; Hypocreomycetidae; Hypocreales; Clavicipitaceae; mitosporic Clavicipitaceae; Aschersonia. This fungus was firstly used for controlling whiteflies in citrus groves in Florida in the early 1900s (1), where a combination of predators, parasitoids with $A$. aleyrodis successfully controlled the citrus whiteflies Dialeurodes citri and D. citrifolii for decades (12). Previous researches have indicated that $A$. aleyrodis is a promising whitefly control agent because of its long persistence on leaf surfaces $(6,13)$ and its compatibility with Encarsia formosa $(7,8)$. Along with A. aleyrodis several other species of the genus Aschersonia have been reported on whitefly species all over the world $(11,14,15)$. This genus is known to cause severe epizootics in whitefly (Aleyrodidae) and scale insects (Coccidae) in the tropics and subtropics (4). Epizootics of A. aleyrodis have been reported from Bemisia tabaci populations; however, most microbial control efforts with this fungus have targeted the greenhouse whitefly, Trialeurodes vaporariorum (9).

Mycelial growth and sporulation on artificial media are important biological characteristics of fungi, including $A$. aleyrodis. And the nutritional requirements can have a profound effect on culture growth, conidiation and morphology in insect pathogenic fungi. However, to the best of our knowledge, the nutritional requirements of $A$. aleyrodis have not been demonstrated so far. Also, there has been no suitable medium for the cultivation of $A$. aleyrodis till now, and this fungal pathogen does not grow well in any known medium. In order to further facilitate the physiological study of this fungus and its application in biocontrol more information is required. The first step is to increase the biomass and sporulation in an artificial culture. Generally, the media used in large scale fermentations

*Corresponding Author. Mailing address: Key Laboratory of Biopesticide and Chemical Biology, Ministry of Education, Fujian Agriculture and Forestry University, Fuzhou 350002, China. E-mail: guanxfafu@126.com or gxfafu@fjau.edu.cn 
of entomopathogenic fungi contain raw natural materials, such as corn steep powder, potato, soya bean, etc., and the chemical compounds of the media were not quantifiable. Although these raw components of media may have the advantage of low cost, it may not be possible to control the quality of the A. aleyrodis mycelial product and sporulation for the heterogeneity or batch variation of the natural components. Because of the unquantified chemical constituents, the study on physiological and biochemical characters of A. aleyrodis can not be performed in these media. To further study the physiology of $A$. aleyrodis and improve mycelial growth and sporulation of A. aleyrodis, as well as to quantify the compounds used in cultivation media, synthetic or semi-synthetic media are required.

In a previous experiment, 12 carbon sources (dextrose, sucrose, D-xylose, lactose, maltose, D-fructose, soluble starch, inositol, mannitol, D-galactose, $\alpha$-Lactose, sorbitol), 10 nitrogen sources $\left(\left(\mathrm{NH}_{4}\right)_{2} \mathrm{SO}_{4}, \mathrm{NaNO}_{3}, \mathrm{NH}_{4} \mathrm{NO}_{3}\right.$, urea, yeast powder, tryptone, casein, peptone, beef extract, yeast extract), 6 metal ions $\left(\mathrm{Cu}^{2+}, \mathrm{Mn}^{2+}, \mathrm{Zn}^{2+}, \mathrm{Fe}^{2+}, \mathrm{Fe}^{3+}, \mathrm{Ca}^{2+}\right)$ and 6 vitamins $\left(\mathrm{V}_{\mathrm{B} 1}, \mathrm{~V}_{\mathrm{B} 2}\right.$, $\mathrm{V}_{\mathrm{B} 5}, \mathrm{~V}_{\mathrm{C}}, \mathrm{V}_{\mathrm{B} 6}$, folacin) were studied using one-factor-at-a-time method in order to evaluate the effects of various $\mathrm{C}$ and $\mathrm{N}$ sources, metal ions and vitamins on mycelial growth and sporulation of this fungus. For the $\mathrm{C}$ source test, $7 \mathrm{~g}$ of $\mathrm{C}^{-1}$ each carbohydrate was added individually to the basal medium (dextrose $2 \%(\mathrm{w} / \mathrm{v})$, $\left(\mathrm{NH}_{4}\right)_{2} \mathrm{SO}_{4} 0.2 \%$ (w/v), $\mathrm{KCl} 0.05 \%$ (w/v), $\mathrm{MgSO}_{4} 0.05 \%$ (w/v), $\mathrm{KH}_{2} \mathrm{PO}_{4} 0.05 \%$ (w/v), $\mathrm{Na}_{2} \mathrm{HPO}_{4} 0.065 \%$ (w/v) and distilled water) to replace dextrose and a basal medium free of any $\mathrm{C}$ was served as a control. For the $\mathrm{N}$ source test, $0.5 \mathrm{~g}_{\text {of N }}{ }^{-1}$ each $\mathrm{N}$ compound was added respectively to the basal medium to replace $(\mathrm{NH} 4)_{2} \mathrm{SO}_{4}$ and a basal medium without $\mathrm{N}$ acted as a control. For the metal ions test, $4 \times 10^{-4} \mathrm{~mol}$ each metal ion was added to $1 \mathrm{~L}$ basal medium, respectively, and basal medium was served as a control. For vitamin test, $100 \mathrm{mg}$ each vitamin was added to $1 \mathrm{~L}$ basal medium, respectively, and basal medium was served as a control. According to the results of previous study, we found that the best nutrient components for the mycelial growth of this fungus included soluble starch, tryptone, $\mathrm{Ca}^{2+}$ and folacin, while the best nutrient components for sporulation included lactose, tryptone, $\mathrm{Fe}^{2+}$ and $V_{B 1}$ (18). After the best nutrient components for this fungus were screened out, the effective concentrations of these components were further investigated by the concentration gradient experiments of each component. The experiment procedures are similar to that of one-factor-at-a-time experiments described above, and the 7 different concentrations of each best component replaced the corresponding $\mathrm{C}$ or $\mathrm{N}$ source of basal medium or added into the basal medium individually (data not shown). Based on the results of these experiments 3 effective concentrations of each component listed in Table 1 and 2 respectively were chosen for optimization experiments.

In this paper, the optimal nutrient requirements were studied by orthogonal matrix method on the basis of previous work in order to get more information of the fungus.
Table 1. $\mathrm{L}_{9}\left(3^{4}\right)$ orthogonal design on optimization of culture medium for mycelial growth.

\begin{tabular}{ccccc}
\hline Factors & $\begin{array}{c}\text { Soluble starch } \\
(\mathrm{SS})^{\mathrm{a}} \\
(\% \mathrm{w} / \mathrm{v})\end{array}$ & $\begin{array}{c}\text { Tryptone } \\
(\mathrm{TR}) \\
(\% \mathrm{w} / \mathrm{v})\end{array}$ & $\begin{array}{c}\mathrm{Ca}^{2+} \\
\left(\mathrm{mmoll}^{-1}\right)\end{array}$ & $\begin{array}{c}\text { Folacin } \\
(\mathrm{FO}) \\
(\% \mathrm{w} / \mathrm{v})\end{array}$ \\
\hline Level 1 & 0.79 & 0.79 & 0.2 & 0.005 \\
Level 2 & 1.58 & 1.58 & 0.4 & 0.01 \\
Level 3 & 3.16 & 3.16 & 0.8 & 0.02 \\
\hline
\end{tabular}

a SS, TR and FO represent factors of soluble starch, tryptone and folacin respectively.

Table 2. $\mathrm{L}_{9}\left(3^{4}\right)$ orthogonal design on optimization of culture medium for sporulation.

\begin{tabular}{ccccc}
\hline Factors & $\begin{array}{c}\text { Lactose } \\
(\mathrm{LA})^{\mathrm{a}} \\
(\% \mathrm{w} / \mathrm{v})\end{array}$ & $\begin{array}{c}\text { Tryptone } \\
(\mathrm{TR}) \\
(\% \mathrm{w} / \mathrm{v})\end{array}$ & $\begin{array}{c}\mathrm{Fe}^{2+} \\
\left(\mathrm{mmoll}^{-1}\right)\end{array}$ & $\begin{array}{c}\mathrm{V}_{\mathrm{B1}} \\
(\mathrm{FO}) \\
(\% \mathrm{w} / \mathrm{v})\end{array}$ \\
\hline Level 1 & 0.29 & 0.197 & 0.2 & 0.00125 \\
Level 2 & 0.58 & 0.394 & 0.4 & 0.0025 \\
Level 3 & 1.16 & 0.788 & 0.8 & 0.005 \\
\hline
\end{tabular}

${ }^{\text {a }}$ LA and TR represent factors of lactose and tryptone respectively.

\section{MATERIALS AND METHODS}

\section{Fungal isolates}

Based on previous bioassays against whitefly using 40 strains of A. aleyrodis isolated by our laboratory, strain labelled JO009 was selected for this study. The strain was originally isolated from a citrus whitefly $D$. citri from a citrus-growing orchard in Fujian, China, in 2000. A single-spore isolate of JO009 was stored in $20 \%$ glycerol at $-80^{\circ} \mathrm{C}$ and transferred once every 4 months. Cultures were grown on potato dextrose agar (PDA) at $25^{\circ} \mathrm{C}$ with a daily cycle consisting of $15 \mathrm{~h}$ of light and $9 \mathrm{~h}$ of darkness. The strain was inoculated twice in sweet-potato whitefly (B. tabaci) before using in the assay.

\section{Inoculum preparation}

Spores of this fungus were harvested from potato dextrose agar (PDA) slant cultures after incubation at $25 \pm 1^{\circ} \mathrm{C}$ for 2 weeks, then transferred into $50 \mathrm{ml}$ sterile solution containing $0.05 \%$ Tween 80 , and stirred with a magnetic stirrer for $30 \mathrm{~min}$ to dislodge and suspend the spores and finally passed through three layers gauze (or 100-mesh sieve). Spores were counted by using a haemacytometer and adjusted with sterile $0.05 \%$ Tween 80 solution to produce final concentrations of $1.66 \times 10^{7}$ spores $\mathrm{ml}^{-1}$. 


\section{Orthogonal layout}

Based on the results of our previous work, the screened nutrient components which are most suitable for mycelial growth and sporulation of $A$. aleyrodis and the 3 effective concentrations of each component were further optimized using the orthogonal layout $\mathrm{L}_{9}\left(3^{4}\right)$. The levels of components of the media for mycelial growth and sporulation are shown in Table 1 and 2, respectively.

Besides the screened $\mathrm{C}$ sources, $\mathrm{N}$ sources, metal ions and vitamins listed in Table 1 and 2, media used in present experiment also contained $0.05 \%$ (w/v) KCl, $0.05 \%$ (w/v) $\mathrm{MgSO}_{4}, 0.05 \%$ (w/v) $\mathrm{KH}_{2} \mathrm{PO}_{4}, 0.065 \%(\mathrm{w} / \mathrm{v}) \mathrm{Na}_{2} \mathrm{HPO}_{4}$ and $2 \%-5 \%$ agar (agar is not added in media for mycelial growth). Metal ions were provided with $\mathrm{ZnSO}_{4} 7 \mathrm{H}_{2} \mathrm{O}, \mathrm{FeSO}_{4} 7 \mathrm{H}_{2} \mathrm{O}$ and $\mathrm{CaCl}_{2}$ respectively. Metal ions and $\mathrm{V}_{\mathrm{B} 1}$ were sterilized by filtering with a $0.2-\mu \mathrm{m}$ aperture filter and were added to the sterile medium under sterile conditions. Other vitamins were added to the medium prior to heat sterilization $(2,16)$.

\section{Analytical methods}

For mycelial growth test, $200 \mu \mathrm{l}$ spore inoculum was added into $500 \mathrm{ml}$ flasks each containing $200 \mathrm{ml}$ of liquid medium and then cultured in a rotatory shaker at $150 \mathrm{rpm}$ and $25 \pm 1^{\circ} \mathrm{C}$. After $7 \mathrm{~d}$, the mycelial biomasses were harvested by vacuum filtration with pre-dried and weighed filter papers and then mycelium was dried at $80^{\circ} \mathrm{C}$ for $24 \mathrm{~h}$. The growth was estimated by the dry weight of mycelium. Each treatment was repeated three times.

For sporulation test, $200 \mu \mathrm{l}$ spore inoculum was transferred onto the center of each petri plate $(9 \mathrm{~cm}$ in diameter) containing $15 \mathrm{ml}$ solid media, sealed with parafilm, and then placed in an incubator at $74 \%$ relative humidity $(\mathrm{RH})$ and $25 \pm 1^{\circ} \mathrm{C}$. After $22 \mathrm{~d}$, spores were washed with $10 \mathrm{ml} 0.05 \%$ Tween 80 solution and stirred on a magnetic stirrer for $30 \mathrm{~min}$ and then passed through three layers gauze (or 100-mesh sieve). The number of spores was determined using a hemocytometer with the aid of a microscope (magnification $\times 300$ ). Four duplications were made for each treatment.

\section{Statistical analysis}

Data of orthogonal tests were analyzed using variance analysis. Differences of $F<0.05$ or $F>0.01$ were considered different significant levels.

\section{RESULTS}

\section{Mycelial growth test}

Factors and levels of orthogonal layout $\mathrm{L}_{9}\left(3^{4}\right)$ for mycelial growth are shown in Table 1, and the conditions for each experimental group are listed in Table 3 including the results in the last column. As shown in Table 3, the maximum production of mycelia $\left(17.75 \mathrm{~g} \mathrm{l}^{-1}\right)$ occurred in the sixth experimental group whose condition was: SS-2, TR-3, $\mathrm{Ca}^{2+}-1$ and FO-2, namely soluble starch $(1.58 \%)$, tryptone (3.16\%), $\mathrm{Ca}^{2+}\left(0.2 \mathrm{mmoll}^{-1}\right)$ and folacin $(0.01 \%)$, respectively. According to the magnitude order of $R$ (maximum difference) in the last row of Table 3, the order of the effect of all factors on mycelial growth could be determined. The order of effects of factors on mycelial growth was tryptone $(66.99)>\mathrm{Ca}^{2+}(32.31)>$ soluble starch (29.72) > folacin (15.53). This result pointed out that the effect of tryptone was more important than that of other nutrients. The result that tryptone had the largest $F$ ratio (48.85) (Table 4 ) also demonstrated thus.

Table 3. The results of $\mathrm{L}_{9}\left(3^{4}\right)$ orthogonal test of mycelial growth.

\begin{tabular}{cccccc}
\hline $\begin{array}{c}\text { Experimental } \\
\text { group }\end{array}$ & $\mathrm{SS}^{\mathrm{a}}$ & $\mathrm{TR}$ & $\mathrm{Ca}^{2+}$ & $\mathrm{FO}$ & $\begin{array}{c}\text { Mycelial dry } \\
\text { weight }\left(\mathrm{g} \mathrm{l}^{-1}\right)^{\mathrm{b}}\end{array}$ \\
\hline 1 & 1 & 1 & 1 & 1 & $7.30 \pm 0.54$ \\
2 & 1 & 2 & 2 & 2 & $4.32 \pm 1.19$ \\
3 & 1 & 3 & 3 & 3 & $10.65 \pm 1.81$ \\
4 & 2 & 1 & 2 & 3 & $5.29 \pm 1.08$ \\
5 & 2 & 2 & 3 & 1 & $9.13 \pm 3.83$ \\
6 & 2 & 3 & 1 & 2 & $17.75 \pm 1.58$ \\
7 & 3 & 1 & 3 & 2 & $6.84 \pm 1.73$ \\
8 & 3 & 2 & 1 & 3 & $8.69 \pm 1.51$ \\
9 & 3 & 3 & 2 & 1 & $13.37 \pm 2.19$ \\
$\mathrm{~K}_{1}{ }^{\mathrm{c}}$ & 66.79 & 58.29 & 101.24 & 89.39 & \\
$\mathrm{~K}_{2}$ & 96.51 & 66.41 & 68.93 & 86.73 & \\
$\mathrm{~K}_{3}$ & 86.68 & 125.28 & 79.81 & 73.86 & \\
$R^{\mathrm{d}}$ & 29.72 & 66.99 & 32.31 & 15.53 & \\
\hline
\end{tabular}

a SS, TR and FO represent factors of soluble starch, tryptone and folacin respectively.

b Values are mean \pm SD of triple determinations.

c $\mathrm{K}_{1}, \mathrm{~K}_{2}$ and $\mathrm{K}_{3}$ are the total content of mycelial dry weight from level 1 , level 2 and level 3 respectively.

d $R$ is the maximum of $\mathrm{K}_{1}, \mathrm{~K}_{2}$ and $\mathrm{K}_{3}$ minus the minimum of $\mathrm{K}_{1}, \mathrm{~K}_{2}$ and $\mathrm{K}_{3}$, respectively.

Table 4. The variance analysis of $\mathrm{L}_{9}\left(3^{4}\right)$ orthogonal test on mycelial growth.

\begin{tabular}{ccc}
\hline Variance source & $F$ ratio $^{\mathrm{b}}$ & Significance level $^{\mathrm{c}}$ \\
\hline $\mathrm{SS}^{\mathrm{a}}$ & 8.38 & $* *$ \\
$\mathrm{TR}$ & 48.85 & $* *$ \\
$\mathrm{Ca}^{2+}$ & 9.88 & $* *$ \\
$\mathrm{FO}$ & 2.52 & \\
\hline
\end{tabular}

a SS, TR and FO represent soluble starch, tryptone and folacin respectively.

b The degrees of freedom for all factors are all 2. And the degree of freedom for error is 18 .

c $F_{0.05}(2,18)=3.55 ; F_{0.01}(2,18)=6.01 ; * F_{0.05}<F$ ratio $<F_{0.01} ; * * F$ ratio $>F_{0.01}$. 
In addition, the variance analysis shown in Table 4 indicated that those factors affected the mycelial growth of A. aleyrodis significantly except folacin whose $F$ ratio (2.52) was smaller than the value of $F_{0.05}(2,18)$.

Optimal level of each medium ingredient for the mycelial growth of A. aleyrodis was determined in terms of the maximum $\mathrm{K}$ value of each column in Table 3 . The optimum compositions were SS-2, TR-3, $\mathrm{Ca}^{2+}-1$ and FO-1 (1.58\% soluble starch, 3.16\% tryptone, $0.2 \mathrm{mmol} \mathrm{l}^{-1} \mathrm{Ca}^{2+}, 0.005 \%$ folacin). To confirm these data, experiments were carried out using these nutrient concentrations and $20.05 \mathrm{~g} \mathrm{l}^{-1}$ of mycelial biomass was obtained. This implied that the selected conditions were the most suitable in practice.

\section{Sporulation test}

According to the four factors and three levels of the orthogonal layout for sporulation (Table 2), the conditions for each experimental group were listed in Table 5 with the results concluded in the last column. From the Table 5, it could be found that the highest mean yield of spore $\left(4.79 \times 10^{10}\right.$ spores $\left.1^{-1}\right)$ by $A$. aleyrodis was reached at the ninth experimental group and the corresponding condition was: LA-3, TR-3, $\mathrm{Fe}^{2+}-2$ and $\mathrm{V}_{\mathrm{B} 1}-1$, namely $1.16 \%$ lactose, $0.788 \%$ tryptone, $0.4 \mathrm{mmol}^{-1} \mathrm{Fe}^{2+}$ and $0.00125 \% \mathrm{~V}_{\mathrm{B} 1}$, respectively. Based on the magnitude order of $R$ value shown in the last row of Table 5, the order of effects of all factors on sporulation of $A$. aleyrodis was estimated

Table 5. The results of $\mathrm{L}_{9}\left(3^{4}\right)$ orthogonal test of sporulation.

\begin{tabular}{cccccc}
\hline $\begin{array}{c}\text { Experimental } \\
\text { group }\end{array}$ & LA $^{\mathrm{a}}$ & $\mathrm{TR}$ & $\mathrm{Fe}^{2+}$ & $\mathrm{V}_{\mathrm{B} 1}$ & $\begin{array}{c}\text { Sporulation } \\
\left(\times 10^{10} \text { spores } \mathrm{l}^{-1}\right)^{\mathrm{b}}\end{array}$ \\
\hline 1 & 1 & 1 & 1 & 1 & $1.67 \pm 0.25$ \\
2 & 1 & 2 & 2 & 2 & $1.42 \pm 0.23$ \\
3 & 1 & 3 & 3 & 3 & $0.23 \pm 0.09$ \\
4 & 2 & 1 & 2 & 3 & $1.06 \pm 0.23$ \\
5 & 2 & 2 & 3 & 1 & $1.40 \pm 0.86$ \\
6 & 2 & 3 & 1 & 2 & $0.52 \pm 0.24$ \\
7 & 3 & 1 & 3 & 2 & $1.83 \pm 0.47$ \\
8 & 3 & 2 & 1 & 3 & $2.98 \pm 0.51$ \\
9 & 3 & 3 & 2 & 1 & $4.79 \pm 1.22$ \\
$\mathrm{~K}_{1}^{\mathrm{c}}$ & 13.26 & 18.23 & 20.67 & 31.41 & \\
$\mathrm{~K}_{2}$ & 11.90 & 23.19 & 29.03 & 15.06 & \\
$\mathrm{~K}_{3}$ & 38.40 & 22.14 & 13.86 & 17.09 & \\
$R^{\mathrm{d}}$ & 26.50 & 4.96 & 15.17 & 16.35 & \\
\hline
\end{tabular}

a LA and TR represent factors of lactose and tryptone respectively.

b Values are mean \pm SD of tetrad determinations.

c $\mathrm{K}_{1}, \mathrm{~K}_{2}$ and $\mathrm{K}_{3}$ are the total content of spore yield from level 1, level 2 and level 3 respectively.

d $R$ is the maximum of $\mathrm{K}_{1}, \mathrm{~K}_{2}$ and $\mathrm{K}_{3}$ minus the minimum of $\mathrm{K}_{1}, \mathrm{~K}_{2}$ and $\mathrm{K}_{3}$, respectively. respectively. The order of effects of all factors on sporulation was lactose $(26.50)>\mathrm{V}_{\mathrm{B} 1}(16.35)>\mathrm{Fe}^{2+}(15.17)>$ tryptone (4.96). This result indicated that the effect of lactose was more important than that of other factors. To test the effects of the four factors, the variance analysis was used and shown in Table 6. Three factors, including lactose, $\mathrm{Fe}^{2+}$ and $\mathrm{V}_{\mathrm{B} 1}$, whose $F$ ratios were all larger than the value of $F(2,27)$ when the $\mathrm{P}$ value is 0.01 , had extremely significant effects on sporulation of A. aleyrodis, especially lactose whose $F$ ratio (50.16) is the largest of all, whereas tryptone $(F$ ratio $=1.54)$ did not display significant influence on sporulation of this fungus.

In terms of the maximum $\mathrm{K}$ value of each column in Table 5, optimal level of each medium ingredient for the sporulation was LA-3 / TR-2 / Fe ${ }^{2+}-2$ / $\mathrm{V}_{\mathrm{B} 1}-1$. To obtain a high spore yield, the optimum composition should be $1.16 \%$ lactose, $0.394 \%$ tryptone, $0.4 \mathrm{mmol} \mathrm{l}^{-1} \mathrm{Fe}^{2+}$ and $0.00125 \% \mathrm{~V}_{\mathrm{B} 1}$. To confirm these data, experiments were carried out using these nutrient concentrations and $5.23 \times 10^{10}$ spores $1^{-1}$ of spore yield were obtained. And the germination rate of spores on water agar plate achieved $100 \%$ after incubated in an incubator at $74 \% \mathrm{RH}$ and $25 \pm 1^{\circ} \mathrm{C}$ for $16 \mathrm{~h}$.

Table 6. The variance analysis of $\mathrm{L}_{9}\left(3^{4}\right)$ orthogonal test on sporulation.

\begin{tabular}{ccc}
\hline Variance source & $F$ ratio $^{\mathrm{b}}$ & Significance level $^{\mathrm{c}}$ \\
\hline $\mathrm{LA}^{\mathrm{a}}$ & 50.16 & $* *$ \\
$\mathrm{TR}$ & 1.54 & \\
$\mathrm{Fe}^{2+}$ & 13.00 & $* *$ \\
$\mathrm{~V}_{\mathrm{B} 1}$ & 17.89 & $* *$ \\
\hline
\end{tabular}

a LA and TR represent lactose and tryptone respectively.

b The degrees of freedom for all factors are all 2. And the degree of freedom for error is 27 .

c $F_{0.05}(2,27)=3.35 ; F_{0.01}(2,27)=5.49 ; * F_{0.05}<F$ ratio $<F_{0.01} ; * * F$ ratio $>F_{0.01}$.

\section{DISCUSSION}

Culture media has been shown to influence the germination, mycelial growth, sporulation and virulence of fungi employed as mycoinsecticides $(5,10)$. In previous work, we firstly reported effects of 12 carbon sources, 11 nitrogen sources, 6 metal ions and 6 vitamins on growth and development of A. aleyrodis (18). According to the results of our previous study, optimization of nutritional requirements and design of simplified semi-synthetic media for mycelial growth and sporulation of A. aleyrodis were firstly reported in this paper.

The conventional variation of one-factor-at-a-time approach of optimization is not only time-consuming but often incapable of reaching the true optimum due especially to the interactive effects among factors. Orthogonal layout can give effective 
responses because of the suitable design of factor. In comparison with the full-factors experimental design, orthogonal design can reduce experimental difficulties and reveal the interactions of factors $(3,17)$. In the present experiment, the orthogonal matrix method has helped us to understand the nutritional requirements of mycelial growth and sporulation of A. aleyrodis and obtain the optimal media including the ratio of each medium component.

By using chemically synthetic media, the effect of medium components on nutritional requirements of mycelial growth and sporulation of A. aleyrodis can be studied in detail. Moreover, process consistency is enhanced because the chemically semidefined media inherently supports a more reproducible process. The optimized media designed in this study is useful for the investigation of fermentation kinetics of mycelial growth in $A$. aleyrodis and can also be used to produce mycelial and spore products of consistent quality. There are many factors (i.e. temperature, humidity, $\mathrm{pH}$, etc.) which can influence A. aleyrodis, and there must be interactions among these factors. Basic and essential information for the mass production of A. aleyrodis in culture allows for some insights into the physiology of this fungus. It is necessary to further research the other factors and optimize the fermentation conditions in a fermenter using complex media to achieve the demands of large-scale mycelial production and sporulation, which are an ongoing project in this laboratory.

\section{ACKNOWLEDGEMENTS}

This research was supported by grants from Chinese National Natural Science Foundation (30500005), Key Project of Fujian Provincial Programs for Science and Technology (2006S0002), Fujian Provincial Programs for Science and Technology (2007F5022) and Fujian Provincial Natural Science Foundation (B0610007).

\section{RESUMO}

\section{Otimização das exigências nutricionais para crescimento micelial e esporulação do fungo entomopatogênico Aschersonia aleyrodis Webber}

O objetivo deste estudo foi investigar as exigências nutricionais ótimas para o crescimento micelial e esporulação do fungo entomopatogênico Aschersonia aleyrodis Webber. A ordem dos efeitos dos nutrientes na multiplicação micelial foi triptona $>\mathrm{Ca}^{2+}>$ amido solúvel $>$ folacina, com as seguintes concentrações ótimas: amido solúvel 1,58\%, tritona 3,16\%, $\mathrm{Ca}^{2+}$ $0,2 \mathrm{mmol}^{-1} \mathrm{I}^{-1} \mathrm{e}$ folacina $0,005 \%$. Para a esporulação, a concentração ótima de cada fator foi: lactose $1,16 \%$, triptona $0,394 \%, \mathrm{Fe}^{2+}$ 0,4mmol.l-1 e $\mathrm{V}_{\mathrm{B} 1} 0,00125 \%$, na seguinte ordem: lactose $>\mathrm{V}_{\mathrm{B} 1}>$ $\mathrm{Fe}^{2+}>$ tritona. Em condições ótimas de cultura, a produção máxima de micélio foi 20,05g. $\mathrm{l}^{-1}$ após 7 dias de fermentação, enquanto o rendimento máximo de esporos foi $5,23 \times 10^{10}$ esporos..$^{-1}$ após 22 dias de cultivo. Esse é o primeiro relato sobre otimização das exigências nutricionais e desenvolvimento de meio de cultura semi-sintético para crescimento micelial e esporulação de A. aleyrodis.

Palavras-chave: Fungo entomopatogênico, Aschersonia aleyrodi, método matriz ortogonal, crescimento micelial, esporulação

\section{REFERENCES}

1. Berger, E.W. (1921). Natural enemies of scale insects and whiteflies. Quarterly Bulletin of Florida State Plant Board., 5, 141-154.

2. Blaudez, D.; Jacob, C.; Turnau, K.; Colpaert, J.V.; Ahonen-Jonnarth, U.; Finlay, R.; Botton, B.; Chalot, M. (2000). Differential responses of ectomycorrhizal fungi to heavy metals in vitro. Mycol. Res., 104 (11), 1366-1371.

3. Dong, C.H.; Yao, Y.J. (2005). Nutritional requirements of mycelial growth of Cordyceps sinensis in submerged culture. J. Appl. Microbiol., 99, 483-492.

4. Evans, H.C.; Hywel-Jones, N. (1990). Aspects of the genera Hypocrella and Aschersonia as pathogens of coccids and whiteflies. Proceedings and Abstracts, 5th International Colloquium of Invertebrate Pathology and Microbial Control. Adelaide, Australia, p. 111-115.

5. Fargues, J.F.; Robert, P.H. (1983). Effect of passaging through scarabeid hosts on the virulence and host specificity of two strains of the entomopathogenic hyphomycete Metarhizium anisopliae. Can. J. Microbiol., 29, 576-583.

6. Fransen, J.J. (1996). Survival of spores of the entomopathogenic fungus Aschersonia aleyrodis (Deuteromycotina: Coelomycetes) on leaf surfaces. J. Invertebr. Pathol., 65, 73-75.

7. Fransen, J.J.; van Lenteren, J.C. (1993). Host selection of the parasitoid Encarsia formosa on greenhouse whitefly, Trialeurodes vaporariorum, in the presence of hosts infected with the fungus Aschersonia aleyrodis. Entomol. Exp. Appl., 69, 239-249.

8. Fransen, J.J.; van Lenteren, J.C. (1994). Survival of the parasitoid Encarsia formosa after treatment of parasitized greenhouse whitefly larvae with fungal spores Aschersonia aleyrodis. Entomol. Exp. Appl., 71, 235-243.

9. Lacey, L.A.; Fransen, J.J.; Carruthers, R. (1996). Global distribution of naturally occurring fungi of Bemisia, their biologies and use as biological control agents. In: Gerling, D.; Mayer, R.T. (eds). Bemisia 1995: Taxonomy, Biology, Damage Control and Management. Intercept, Andover, p. 401-403.

10. Lane, A.S.; Trinci, A.P.J.; Gillespie, A.T. (1991). Influence of cultural conditions on the virulence of conidia and blastospores of Beauveria bassiana on the green leafhopper, Nephotettix virescens. Mycol. Res., 95, 829-833.

11. Mains, E.B. (1959). North American species of Aschersonia parasitic on Aleyrodidae. J. Insect. Pathol., 1, 43-47.

12. McCoy, C.W. (1985). Citrus: Current status of biological control in Florida. In: Hoy, M.A., Herzog, D.C. (eds.). Biological Control in Agricultural IPM Systems. Academic Press, London, p. 481-499.

13. Meekes, E.T.M.; van Voorst, S.; Joosten, N.N.; Fransen, J.J.; van Lenteren, J.C. (2000). Persistence of the fungal whitefly pathogen Aschersonia aleyrodis, on three different plant species. Mycol. Res., 104, 1234-1240.

14. Petch, T. (1921). Studies in entomogenous fungi: II The genera, Hypocrella and Aschersonia. Ann. R. Bot. Gardens, Peradeniya, 7, 167-278. 
15. Protsenko, E.P. (1967). The importance of the fungus Aschersonia in nature and its practical use by man in the biological control of insects. Sb. Karantinu. Rast., 19, 147-215 (in Russian).

16. Saxena, G.; Dayal, R.; Mukerji, KG. (1989). Nutritional studies on nematode-trapping fungi. Folia. Microbiol., 34, 42-48.

17. Xiao, J.H.; Chen, D.X.; Liu, J.W.; Liu, Z.L.; Wan, W.H.; Fang, N.; Xiao, Y.; Qi, Y.; Liang, Z.Q. 2004). Optimization of submerged culture requirements for the production of mycelial growth and exopolysaccharide by Cordyceps jiangxiensis JXPJ 0109. J. Appl. Microbiol., 96, 1105-1116.

18. Zhu, Y.P.; Qiu, J.Z.; Xie, X.Q.; Pan, J.R.; Zhang, S.S.; Guan, X. (2004). Effects of Carbon Sources, Nitrogen Sources, Metal Ions and Vitamins on Spore Germination, Hyphal Growth and Sporulation of Entomopathogenic fungus Aschersonia aleyrodis Webber. Journal of Xinjiang University [Natural Science Edition]. 21 (z1), 119-123 (in Chinese). 